Vol. 24, No. 2, April 2021, hlm. 239-248

p-ISSN: 1410-9344; e-ISSN: 2549-5631

WARTA LPM

homepage: http://journals.ums.ac.id/index.php/warta

\title{
Perencanaan Keuangan untuk Menumbuhkan Awareness Literasi Keuangan pada Siswa SMA PMB Bandung
}

\author{
${ }^{1}$ Mirza Hedismarlina Yuneline, ${ }^{2}$ Usdi Suryana, ${ }^{3}$ Iim Hilman \\ ${ }^{1,3}$ Program Studi S1 Manajemen, Sekolah Tinggi Ilmu Ekonomi (STIE) Ekuitas, Bandung \\ ${ }^{2}$ Program Studi S1 Akuntansi, Sekolah Tinggi Ilmu Ekonomi (STIE) Ekuitas, Bandung \\ Email: ${ }^{1}$ mirza.yuneline@ekuitas.ac.id , ${ }^{2}$ usdi.suryana@gmail.com, ${ }^{3}$ iim.hilman@ekuitas.ac.id
}

\begin{tabular}{l}
\hline \multicolumn{1}{c}{ Article Info } \\
\hline Submitted: 10 October 2020 \\
Revised: 9 December 2020 \\
Accepted: 30 December 2020 \\
Published: 21 April 2021 \\
Keywords: Financial Literacy, \\
Finacial Planning, Consumptive \\
Behavior
\end{tabular}

Behavior

Kata kunci: Literasi Keuangan, Perencanaan Keuangan, Perilaku Konsumtif.

\begin{abstract}
Referring to the Finacial Service Authority (FSA)'s blueprint in 2015 stated that one of the targets of financial literacy is students who have psychological characteristics related to consumptive behavior, so the group target who have benefits from the Community Service activities are the students of Pendidikan Membangun Bangsa (Education Builds the Nation) - PMB High School Bandung. The purpose of this activities is to build awareness regarding financial literacy among students so they can manage finances and avoid consumptive behavior through financial planning. The activity was carried out on June, $19^{\text {th }}-20^{\text {th }}$, 2020 which was attended by PMB High School students. The method of this Community Service activities is using simple worksheet. They were asked to prepare a monthly cash budget as a form of financial planning by identifying sources of income, types of expenses, the amount of savings as a form of investment and the investment objectives. From the results of the practice of financial planning budget, there are 52\% of the students who experience fund deficit every month. It because the expenditures are identified as NEEDS so they had difficulties on finding funds that can be used for savings. In addition, even though WANTS are reduced, they still cannot cover the funds that must be invested to achieve financial goals.
\end{abstract}

Abstrak
Mengacu kepada cetak biru dari Otoritas Jasa Keuangan (OJK) pada
tahun 2015, bahwa salah satu yang menjadi sasaran literasi keuangan
adalah pelajar yang memiliki karakteristik psikologis yang erat
kaitannya dengan perilaku konsumtif, maka kelompok sasaran yang
memperoleh manfaat kegiatan pengabdian pada masyarakat adalah
para pelajar SMA Pendidikan Membangun Bangsa (PMB) Bandung.
Tujuan dari pengabdian kepada masyarakat ini adalah membangun
awareness terkait literasi keuangan di kalangan para pelajar agar
mereka dapatmengelola keuangan dan menghindariperilaku konsumtif
melalui perencanaan keuangan. Pelaksanaan kegiatan dilakukan


pada tanggal 19-20 Juni 2020 yang diikuti oleh para pelajar SMA PMB. Metode pelaksanaan kegiatan ini adalah dengan menggunakan kertas kerja sederhana. Para pelajar SMA diminta untuk menyusun anggaran kas bulanan sebagai bentuk perencanaan keuangan dengan mengidentifikasikan sumber pendapatan, jenis pengeluaran, besarnya tabungan sebagai bentuk investasi, dan tujuan investasi. Dari hasil praktik menyusun anggaran perencanaan keuangan, masih terdapat $52 \%$ siswa yang mengalami defisit per bulannya. Hal tersebut terjadi karena pengeluaran diidentifikasikan sebagai NEEDS/kebutuhan sehingga agak sulit untuk mencari dana yang dapat dipakai untuk menabung. Selain itu, walaupun WANTS/keinginannya dikurangi, masih belum dapat menutupi dana yang harus diinvestasikan untuk mewujudkan tujuan keuangan.

\section{PENDAHULUAN}

Berdasarkan Global Financial Inclusion Index (Global FIndex) yang dikeluarkan oleh World Bank (2011), hanya 19,6\% penduduk Indonesia dewasa yang memiliki akses atas layanan lembaga keuangan formal. Angka tersebut menunjukkan bahwa Indonesia masih tertinggal jauh dibandingkan dengan negara-negara Asia Tenggara lainnya, seperti Thailand $(77,7 \%)$, Malaysia (66,7\%), Filipina (26,5\%), dan Vietnam $(21,4 \%)$. Hal tersebut menunjukkan bahwa sistem keuangan di Indonesia belum berjalan secara optimal serta masih adanya ruang untuk perbaikan dalam rangka peningkatan akses masyarakat kepada layanan lembaga keuangan.

Lebih lanjut, berdasarkan World Bank (2011) dari 19,6\% penduduk Indonesia yang memiliki akses atas layanan keuangan formal, hanya $52 \%$ yang dilayani oleh lembaga keuangan formal. Dari 52\% yang dilayani oleh lembaga keuangan, 21\%-nya terdiri dari rumah tangga berpendapatan rendah.

Penelitian lebih lanjut menunjukkan bahwa rumah tangga berpendapatan rendah kurang memiliki akses atas layanan keuangan formal memiliki korelasi dengan rendahnya tingkat pendidikan mereka. Hal ini dapat dilihat dari survey World Bank (2011) yang menunjukkan bahwa masyarakat Indonesia dewasa (di atas 15 tahun) dengan pendidikan tamatan SD atau kurang, yang memiliki rekening (account) pada institusi keuangan formal hanya sebesar $10 \%$. Sedangkan masyarakat Indonesia dengan pendidikan tamatan SMP atau lebih, menunjukkan sebesar 29\%.

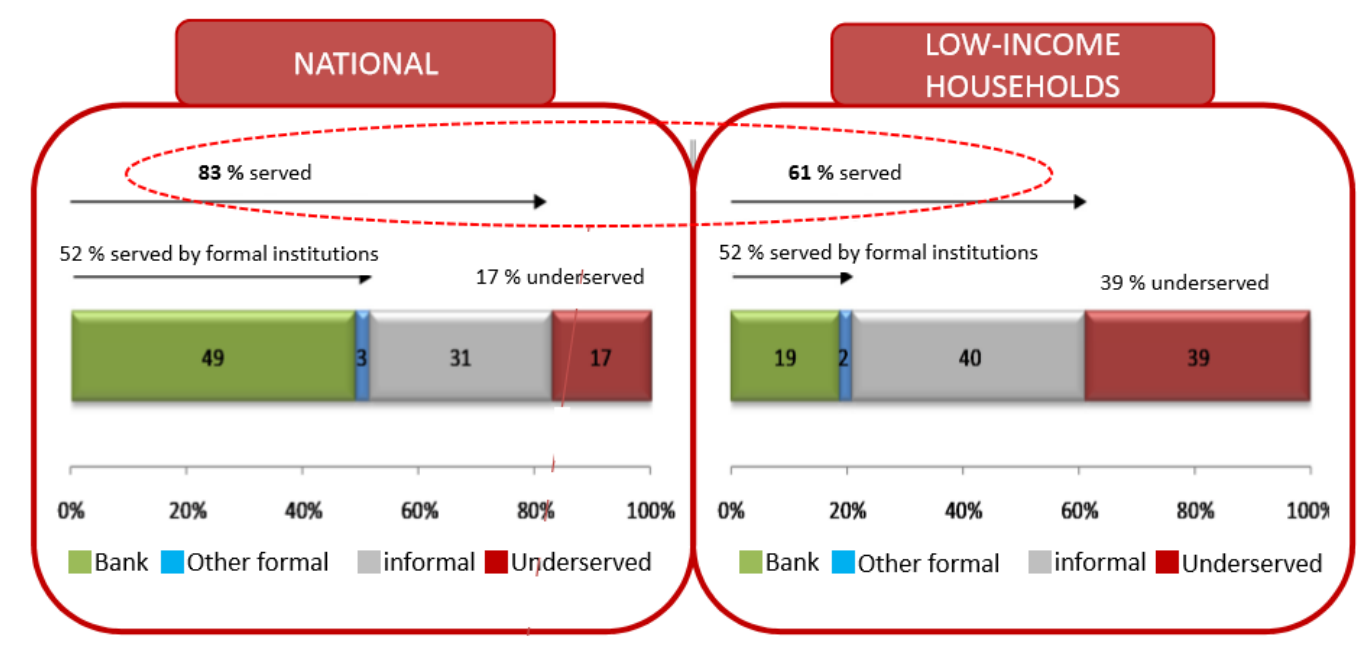

Gambar 1. Akses atas Layanan Keuangan Formal bagi Rumah Tangga Berpendapatan Rendah (Sumber : World Bank, 2011) 
Hal tersebut menunjukkan semakin tinggi tingkat pendidikan seseorang, maka semakin tinggi tingkat kesadaran dalam menggunakan produk keuangan. Dikarenakan rendahnya kesadaran masyarakat dalam penggunaan produk keuangan, menjadikan literasi keuangan menjadi hal yang sangat penting dan hanya dapat dicapai dengan memberikan edukasi keuangan kepada masyarakat.

Bank Indonesia (BI) bersama pemerintah menyusun Strategi Nasional Keuangan Inklusif (SNKI) yang salah satu pilar utamanya adalah edukasi keuangan yang bertujuan untuk meningkatkan tingkat literasi keuangan (financial literacy) masyarakat Indonesia. Pada tahun 2012, Bank Indonesia (BI) melakukan Financial Literacy Baseline Survey (FLBS) yang dilakukan di 5 (lima) provinsi yaitu Sumatera Selatan, Jawa Barat, Kalimantan Barat, Nusa Tenggara Barat, dan Sulawesi Selatan. Hasil survey tersebut menunjukkan sekitar 35\% responden dari 1.920 responden merupakan nasabah bank yang juga menggunakan jasa/ produk bank yang ditawarkan, sedangkan sisanya tidak pernah berhubungan atau tidak lagi aktif menjadi nasabah.

Adapun hasil survey dengan responden yang didominasi oleh tamatan SMA ke bawah, tersebut menunjukkan bahwa aksesibilitas bukan salah satu faktor yang menyebabkan masyarakat tidak mau berhubungan dengan institusi keuangan formal. Terdapat tiga variabel yang memiliki kesamaan hubungan dengan tingkat literasi keuangan yaitu tingkat pendidikan, tingkat pendapatan rumah tangga, dan risk aversion atau kehati-hatian individu dalam mengambil keputusan keuangan. Hubungan yang positif di mana jika ketiga variabel tersebut mengalami peningkatan maka meningkat pula literasi keuangannya.

Bank Indonesia memiliki komitmen dalam meningkatkan edukasi keuangan di kalangan masyarakat Indonesia, di mana edukasi keuangan menjadi bagian dari pilar keenam dalam Arsitektur Perbankan Indonesia, yang bertujuan dengan meningkatkan edukasi keuangan, maka akan meningkatkan literasi keuangan, sehingga akan meningkatkan perlindungan nasabah, dan akan menciptakan stabilitas di sektor perbankan.

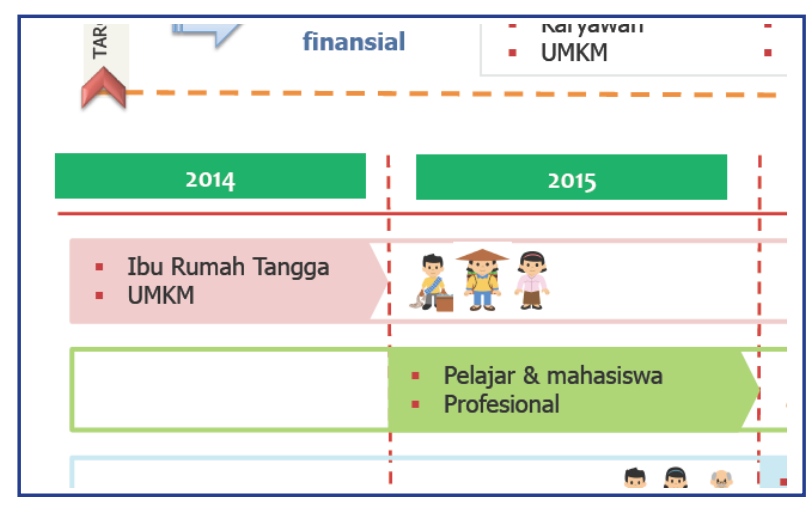

Gambar 2. Sasaran Literasi Keuangan Sumber: http://antaranews.com, diakses pada 6 Januari 2019

Berdasarkan cetak biru dari OJK (http:// antaranews.com, diakses pada 6 Januari 2019), sasaran literasi keuangan dilakukan secara bertahap dan dari berbagai kalangan. Pada tahun 2014, yang menjadi sasaran literasi keuangan adalah ibu rumah tangga dan usaha mikro kecil dan menengah. Berdasarkan Yuneline dan Suryana (2020), tingkat literasi keuangan di kalangan UMKM Kota Bandung tergolong rendah sehingga mempengaruhi terhadap kualitas pengambilan keputusan keuangan.

Berikutnya pada tahun 2015 yang menjadi sasaran adalah pelajar, mahasiswa, dan profesional.

Menurut Kemu (2016) trilogi instrumen kebijakan OJK yaitu inklusi keuangan, literasi keuangan, dan perlindungan konsumen, dilakukan agar sektor keuangan bertumbuh secara berkelanjutan dan terjadi pemberdayaan konsumen. Sehingga kedua hal tersebut dapat jika dapat terlaksana dengan baik, dapat meningkatkan pertumbuhan ekonomi, mengentaskan kemiskinan, dan pemerataan pendapatan.

Sina (2012) menuturkan lebih lanjut, pada prinsipnya literasi keuangan merupakan alat untuk mencapai tujuan, hanya saja pada kenyataannya tidaksemua orang memiliki literasi keuangan yang tinggi sehingga mengerucutkan peluang mencapai kesejahteraan. Salah satu indikatornya adalah menjadi orang yang cerdas dalam mengelola sumber daya ekonominya guna mencapai kesejahteraan dan akan tampak dari pembedahan menggunakan perspektif seperti membangun aset, mengelola utang, menabung, dan lain sebagainya. 


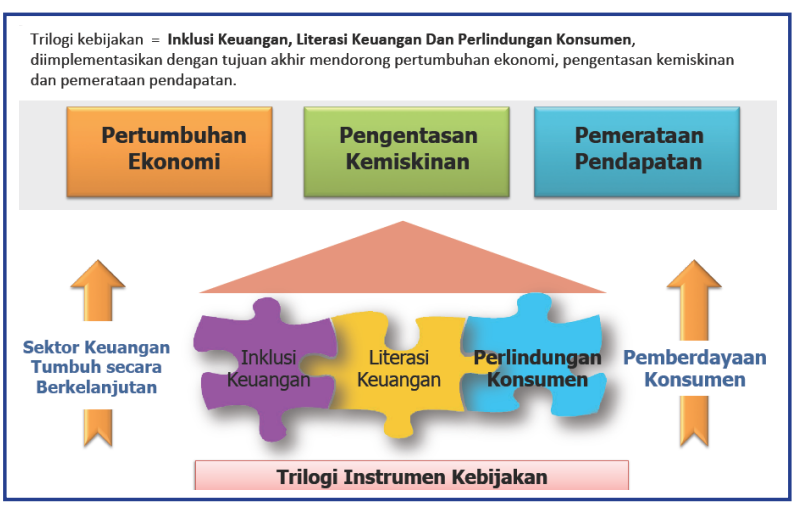

Gambar 3. Sasaran Literasi Keuangan

Sumber: http://antaranews.com, diakses pada 6 Januari 2019

Definisi literasi keuangan menurut Vitt dkk. dalam Huston (2010) adalah kemampuan untuk membaca, menganalisis, mengelola, dan mengkomunikasikan kondisi keuangan personal yang mempengarhi kesejahteraan secara materi. Termasuk kedalamnya adalah kemampuan untuk memahami pilihan investasi, mendiskusikan isu keuangan tanpa merasa tidak nyaman, merencanakan keuangan untuk masa depan, dan merespon secara kompeten terhadap peristiwa dalam hidup yang mempengaruhi pengambilan keputusan keuangan. Sehingga literasi keuangan berkaitan dengan kompetensi seseorang untuk mengelola keuangan. Lebih lanjut menurut Widayati (2015) seseorang dengan kemampuan literasi keuangan dapat mengambil keputusan keuangan dan menerima tanggaung jawab dari keputusan tersebut.

Mengacu kepada cetak biru dari OJK pada tahun 2015, bahwa salah satu yang menjadi sasaran literasi keuangan adalah pelajar, maka kelompok sasaran yang memperoleh manfaat kegiatan pengabdian pada masyarakat adalah pelajar dengan tingkat ekonomi menengah ke bawah. SMA PMB adalah salah satu Sekolah Menengah Atas di kota Bandung dengan mayoritas pelajar berasal dari masyarakat dengan kriteria tersebut. Lulusan dari SMA $\mathrm{PMB}$, mayoritas tidak melanjutkan pendidikan ke jenjang yang lebih tinggi. Berdasarkan wawancara dengan Ketua Yayasan Khalifa Insani yang menaungi SMA PMB, hanya sekitar kurang dari 5\% dari siswa SMA PMB yang melanjutkan kuliah, sisanya langsung mencari pekerjaan sebagai pegawai toserba, cleaning service, ataupun menjadi tukang ojek yang merupakan golongan masyarakat dengan penghasilan yang rendah.

Selain itu, kebiasaan dari para pelajar SMA adalah perilaku konsumtif. Menurut Putri, dkk., (2016), perbedaan antara kebutuhan primer, sekunder, dan tersier kadang tersamarkan di mana perilaku konsumtif sering terjadi ketika dilakukannya kegiatan konsumsi secara berlebihan dan bukan berdasarkan kebutuhannya. Hal tersebut diperkuat oleh Oktafikasari dan Mahmud (2017) yang menyatakan bahwa remaja cenderung memiliki gaya hidup konsumtif dengan konformitas teman sebayanya. Karakteristik psikologis para pelajar biasanya sangat erat kaitannya dengan perilaku konsumtif di mana uang yang dikeluarkan biasanya tidak berdasarkan kebutuhan tetapi dikarenakan aktualisasi diri dan pengaruh dari teman sebayanya. Islami, dkk., (2020) menambahkan, kondisi keuangan orang tua/wali dapat mempengaruhi sikap dan perilaku mahasiswa dalam mengalokasikan uangnya. Mahasiswa tersebut kesulitan dalam pengelolaan keuangan, sehingga cenderung memiliki gaya hidup yang konsumtif.

Hasil penelitian Fattah, dkk., (2018), Mawo, dkk., (2017), dan Yudasella \& Krisnawati (2019) menunjukkan bahwa literasi keuangan berpengaruh negatif terhadap perilaku konsumtif, di mana semakin tinggi kemampuan literasi keuangan maka semakin menurun perilaku konsumtif. Lebih lanjut, Islami, dkk., (2020) menunjukkan bahwa literasi keuangan berpengaruh positif terhadap minat investasi.

Sehingga tujuan dari pengabdian kepada masyarakat ini adalah membangun awareness terkait literasi keuangan di kalangan para pelajar khususnya SMA PMB Bandung ini, agar mereka dapat mengelola keuangan setelah mereka bekerja, sehingga budaya konsumtif maupun kondisi keuangan yang lebih besar pasak daripada tiang dapat dihindari sejak dini, sehingga diharapkan para siswa SMA PMB dapat mempelajari cara-cara yang lebih baik untuk mengelola uang untuk dapat meningkatkan taraf hidupnya. Tujuan khusus dilaksanakannya kegiatan awareness literasi keuangan melalui pendidikan perencanaan keuangan adalah:

1. Memberikan pengetahuan mengenai perencanaan keuangan 
2. Memberikan pengetahuan mengenai pengelolaan keuangan

3. Membiasakan para siswa SMA PMB untuk menyusun anggaran keuangan.

Sehingga manfaat kegiatan pengabdian pada masyarakat bagi kelompok sasaran yang merupakan masyarakat ekonomi lemah yaitu pengembangan pengetahuan dan keterampilan terutama dalam hal pengelolaan keuangan sehingga dapat menjadi lebih cerdas dalam menentukan keputusan ekonomi untuk meningkatkan taraf hidupnya.

\section{METODE}

Metode pelaksanaan pengabdian pada masyarakat terdiri dari prosedur persiapan dan prosedur pelaksanaan pengabdian pada masyarakat. Sebelum dilaksanakannya kegiatan pengabdian pada masyarakat, dilakukan beberapa persiapan sebagai berikut :

a. Melakukan studi pustaka mengenai literasi keuangan dan pendidikan pengelolaan keuangan.

Tim pengabdian pada masyarakat melakukan studi pustaka mengenai literasi keuangan dan pendidikan pengelolaan keuangan. Literasi Keuangan dan Inklusi Keuangan merupakan salah satu tema penelitian unggulan dari STIE Ekuitas, selain itu tim pengabdian pada masyarakat sebelumnya telah melakukan beberapa penelitian terkait literasi keuangan dan inklusi keuangan dengan objek UMKM dan Mahasiswa.

b. Menyusun modul interaktif untuk pelaksanaan pengelolaan keuangan berupa laporan aliran kas sederhana dan anggaran kas sederhana

Modul interaktif ini dibuat agar menarik para siswa untuk mengerjakan laporan aliran kas sederhana dan anggaran kas sederhana. Dibuat dengan sangat mudah, hanya terdiri dari sumber pendapatan, jenis pengeluaran, besarnya uang yang ditabungkan setiap bulannya, serta rencana penggunaan tabungan tersebut sebagai tujuan investasi.

c. Menentukan waktu pelaksanaan dan lamanya kegiatan pengabdian bersamasama dengan pihak SMA PMB.

Pertimbangan SMA PMB sebagai mitra pengabdian pada masyarakat berdasarkan informasi dari alumni SMA PMB yang melanjutkan studi di STIE Ekuitas dan banyak berkontribusi dalam membantu penelitian anggota tim pengabdian pada masyarakat. Melalui yang bersangkutan, tim pengabdian dapat berkoordinasi dengan pemilik Yayasan Khalifa Insani yaitu yayasan pemilik SMA PMB untuk waktu pelaksanaan dan lamanya kegiatan pengabdian pada masyarakat. Salah satu tantangan tentunya pengabdian ini dilakukan pada masa pandemi Covid-19, sehingga waktu pelaksanaan dibagi menjadi beberapa sesi, mengingat jumlah siswa yang ikut serta dalam kegiatan pengabdian ini dibatasi setiap harinya.

Berikut adalah gambaran secara singkat mengenai tahapan sebelum pelaksanaan kegiatan pengabdian pada masyarakat:

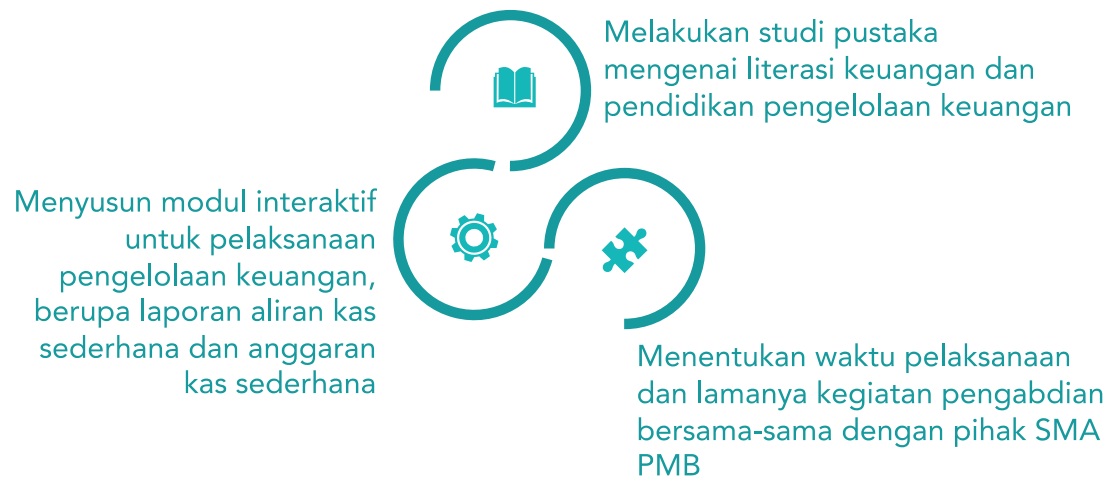

Gambar 4. Persiapan Kegiatan Pengabdian pada Masyarakat 
Pelaksanaan kegiatan pengabdian pada masyarakat berlangsung selama dua hari yaitu pada hari Jumat dan Sabtu tanggal 19 dan 20 Juni 2020, dari pukul 08.00 WIB s.d 17.00 WIB dikarenakan memperhatikan protokol Covid-19 dengan pembatasan jumlah siswa yang mengikuti kegiatan ini. Kegiatan ini dilaksanakan di SMA PMB, Jl. Arcamanik No.31, Mekarmanik, Kec. Cimenyan, Bandung. Kegiatan berupa penyampaian materi dan praktik langsung penyusunan perencanaan keuangan dan anggaran keuangan. Dilakukan secara interaktif dengan siswa dan terdiri dari 4 sesi, yaitu :

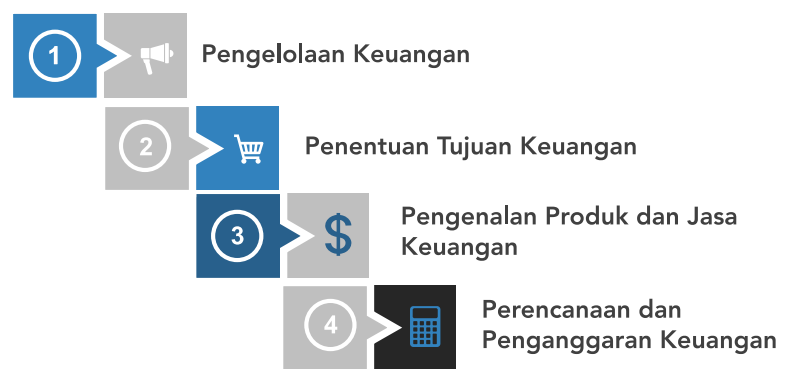

Gambar 5. Pelaksanaan Pengabdian Masyarakat

Pelaksanaan pendidikan perencanaan keuangan melalui beberapa tahapan sebagai berikut:

1. Pengelolaan Keuangan

Dalam mengelola keuangan terdapat beberapa hal penting yang harus dikenali secara bijak, diantaranya sebagai berikut :

a. Sumber Pendapatan

Sumber pendapatan setiap siswa tentunya berbeda. Sumber pendapatan yang dihitung adalah besarnya uang saku yang diterima siswa yang berasal dari orang tua maupun yang berasal dari hasil kontribusi siswa yang mencari tambahan uang saku dengan cara berjualan atau bekerja secara paruh waktu.

b. Pengeluaran

Pengeluaran siswa berupa uang yang diperlukan untuk biaya transportasi ke sekolah, uang yang dikeluarkan untuk jajan atau makan di sekolah, dan biaya pendukung pendidikan seperti untuk fotokopi catatan teman. c. Penentuan Skala Prioritas

Penentuan Skala Prioritas disini adalah perbedaan antara wants (keinginan) dan needs (kebutuhan). Diharapkan dalam penentuan skala prioritas, pengeluaran yang awalnya besar dapat lebih ditekan.

2. Penentuan Tujuan Keuangan

Tujuan keuangan adalah target yang dibuat berdasarkan kebutuhan masa depan siswa. Sehingga siswa dapat menyesuaikan antara tujuan keuangan dengan produk dan jasa keuangan yang tepat dalam mencapai tujuan keuangan tersebut

3. Pengenalan Produk dan Jasa Keuangan

Lembaga Keuangan yang akan diperkenalkan adalah Bank, Asuransi, Koperasi, Pegadaian, dan Pasar Modal. Adapun setiap lembaga memiliki produkproduk sesuai dengan kebutuhan keluarga masing-masing. Bank dapat digunakan untuk menabung, meminjam uang, transfer uang, asuransi, serta membayar tagihan listrik dan telepon. Mengenalkan jenis-jenis asuransi sebagai proteksi bagi keluarga, misalnya asuransi jiwa, asuransi rumah, asuransi kendaraan, asuransi pendidikan, asuransi kesehatan, maupun asuransi kredit. Pegadaian yang dapat digunakan untuk keperluan gadai, pinjaman uang, transfer uang, dan investasi logam mulia. Sedangkan untuk pasar modal dikenalkan pada saham, obligasi, serta reksadana.

Selain mengenalkan mengenai produkproduk jasa lembaga keuangan, siswa juga diberikan pengenalan terkait risiko daripada masing-masing produk, terutama produk bank seperti kredit dan produk investasi yang berisiko seperti obligasi, saham, dan reksadana.

4. Perencanaan dan Anggaran Keuangan

Dalam tahap ini, dilakukan diskusi dengan para siswa terkait hasil dari anggaran kas yang dibuat oleh siswa. Kemudian tim pengabdian secara personal berkomunikasi dengan para siswa untuk menggali tujuan investasi dan bersama-sama mencoba menyusun perencanaan keuangan dengan memperhatikan skala prioritas agar tujuan 
investasi tersebut dapat tercapai. Tentunya dengan menanamkan perubahan perilaku konsumtif menjadi perilaku menabung

Bahan yang digunakan dalam kegiatan pengabdian pada masyarakat adalah lembar kerja untuk membuat laporan kas sederhana dan perencanaan keuangan. Selain itu, tim pengabdian pada masyarakat menyiapkan beberapa uang receh dalam jumlah yang cukup banyak untuk memotivasi siswa agar menabung dengan kondisi sekecil apapun sisa uang yang dimiliki. Alat yang digunakan adalah laptop dan proyektor untuk penyampaian materi pengenalan produk dan jasa keuangan

\section{HASIL DAN PEMBAHASAN}

Berdasarkan wawancara, tanya jawab, dan pengamatan langsung selama kegiatan pengabdian pada masyarakat berlangsung, kegiatan ini memberikan hasil sebagai berikut:

a. Peserta mampu mengidentifikasi sumbersumber pendapatan dan pengeluaran

Dari hasil kegiatan pengabdian pada masyarakat, dari hasil penyusunan sumber pendapatan sebelum masa pandemi Covid-19 berupa uang saku yang diterima oleh para siswa PMB denga kisaran Rp. 10.000 -Rp. 15.000 sebesar 35,70\%; Rp. 16.000- Rp. 20.000 sebesar 30.30\%; Rp. 21.000- Rp. 25.000 sebesar 23\%; dan Rp. 26.000- Rp. 30.000 sebesar 11\%. Dan hanya sekitar $23 \%$ peserta yang memiliki tambahan pendapatan selain uang saku. Tambahan pendapatan didapatkan dengan bekerja membantu orang tua maupun berjualan makanan untuk tambahan uang saku. Sedangkan pada masa pandemi Covid-19, rata-rata pelajar tidak mendapatkan uang saku.
Untuk pengeluaran, uang saku yang dimiliki para siswa biasanya pada masa sebelum pandemic Covid-19 digunakan untuk jajan pada jam istirahat pertama dan makan pada jam istirahat kedua. Ada juga yang menggunakan uang sakunya untuk biaya transportasi dan biaya fotokopi catatan teman.

b. Peserta mampu membedakan antara kebutuhan dan keinginan

Peserta pada awalnya sulit untuk membedakan antara kebutuhan dan keinginan Dikarenakan pengeluaran para peserta sifatnya rutin dilakukan tiap hari, hampir semuanya mengidentifikasikan sebagai NEEDS/kebutuhan sehingga agak sulit untuk mencari dana yang dapat dipakai untuk menabung. Sehingga ratarata para siswa mengeluhkan bahwa setiap bulannya mereka cenderung defisit dengan menghabiskan seluruh uang saku yang mereka terima.

Tetapi sebenarnya hal tersebut dapat disiasati dengan perubahan kebiasaan hidup hemat. Kebiasaan jajan yang merupakan Needs bagi para siswa dapat berubah menjadi Wants dengan membiasakan membawa bekal makanan dari rumah. Biaya fotocopy catatan teman juga dapat dikurangi apabila siswa menjadi lebih rajin mencatat dan memperhatikan materi dari para Guru sekolah.

c. Peserta mampu menetapkan tujuan keuangan

Lebih lanjut lagi, dari hasil kegiatan, 87,5\% peserta memiliki tujuan keuangan untuk membeli handphone. Hal tersebut terjadi, dikarenakan kebutuhan akan handphone berubah seiring dengan adanya pandemi

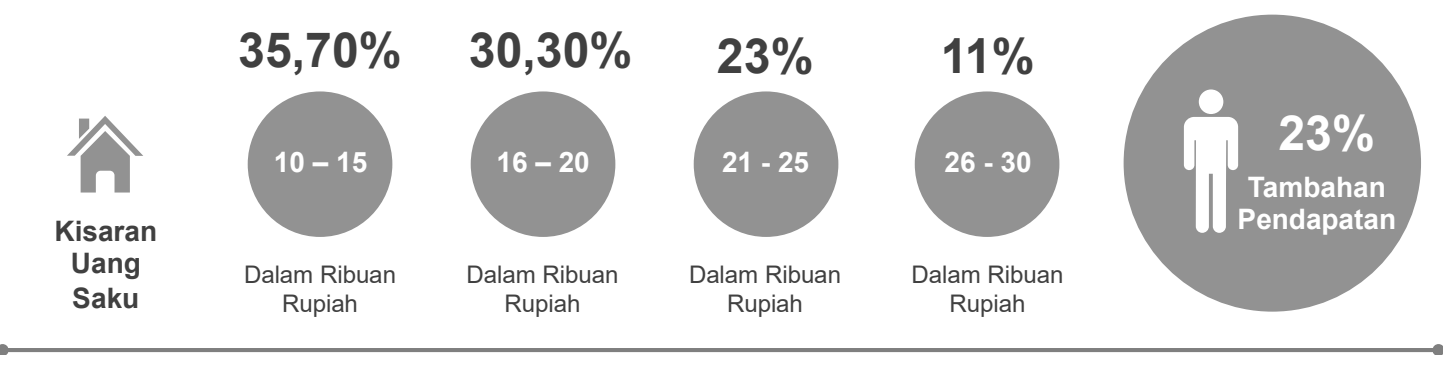

Gambar 6. Kisaran Uang Saku Peserta 
Covid-19 ini, yang sebelumnya kebutuhan tersier menjadi kebutuhan sekunder, di mana para siswa membutuhkan handphone yang mumpuni selain sebagai alat komunikasi tetapi juga menjadi sarana pembelajaran jarak jauh. Kebijakan dari pihak sekolah SMA PMB juga memfasilitasi kondisi ekonomi para siswanya di mana pembelajaran jarak jauh dilakukan secara blended learning di mana materi dan tugas yang diberikan ada juga yang bersifat take home sehingga tidak sepenuhnya menggunakan handphone.

Dari hasil perhitungan aliran kas, masih $52 \%$ masih memiliki kekurangan dalam pendapatan per bulannya. Dikarenakan pengeluaran yang peserta, hampir semuanya mengidentifikasikan sebagai NEEDS/kebutuhan sehingga agak sulit untuk mencari dana yang dapat dipakai untuk menabung. Selain itu, walaupun WANTS/keinginannya dikurangi, masih belum dapat menutupi dana yang harus diinvestasikan untuk mewujudkan tujuan keuangan.

Sehingga dari hasil perhitungan aliran kas, yang paling memungkinkan adalah mengganti tujuan keuangan, dikarenakan pihak sekolah masih memberlakukan pembelajaran secara blended learning. Cara lain yang dapat dilakukan adalah memanfaatkan handphone menjadi aset produktif dengan menggunakannya sebagai sarana mendapatkan tambahan pendapatan seperti berjualan secara online.

d. Peserta mengenal produk dan jasa keuangan Pada kegiatan pengabdian masyarakat ini juga, para siswa dikenalkan dengan produk dan jasa keuangan. Pada saat ini, mereka familiar dengan produk bank seperti tabungan dan produk financial technology seperti Go-Pay maupun OVO. Para peserta dikenalkan juga pada produk pasar modal seperti saham, obligasi, reksadana beserta risiko-risikonya. Dan juga dikenalkan pada produk PT. Pegadaian seperti menabung emas. Selain itu, untuk menjaga dikemudian hari agar para siswa tidak terjebak dalam perilaku konsumtif, dikenalkan juga produk bank seperti kredit dan produk fintech seperti pinjaman online, mereka diberikan pengetahuan mengenai pengambilan keputusan terutama dalam pemilihan kredit. Sehingga jangan sampai di kemudian hari, mereka tidak terlilit hutang hanya untuk memenuhi pengeluaran yang sifatnya wants tersebut.

e. Peserta mengetahui manfaat menabung dan mengetahui tips agar semangat menabung

Dikarenakan para peserta sulit untuk mendapatkan surplus dari aliran kas tiap bulannya, maka yang dapat disarankan adalah menabung di bank dengan produk Tabunganku atau menabung dalam celengan berbentuk uang receh. Walaupun tampak sangat konvensional, tetapi apabila peserta cukup disiplin untuk menyisihkan uang walaupun uang receh dan tergoda untuk membelanjakannya, tujuan keuangan mungkin saja dapat tercapai. Sebagai contohnya, dikemukakan berita viral beberapa waktu lalu di mana ada petani di Majalengka yang membeli mobil menggunakan uang receh (https:// oto.detik.com/mobil/d-4405600/hebohpetani-majalengka-beli-toyota-rush-pakaiuang-receh) sebagai tips agar para pelajar semangat menabung.

f. Peserta mengetahui manfaat menyusun anggaran rencana keuangan, mampu menyusun anggaran keuangan dan mulai mencatat pengeluaran harian.

Pada kegiatan ini, para peserta melakukan praktik penyusunan anggaran rencana keuangan. Adapun data-data yang dikemukakan di atas adalah hasil dari pencatatan pengeluaran harian para siswa. Dengan pembiasaan menyusun anggaran rencana keuangan, para siswa dapat memperkirakan surplus maupun defisit dari keuangannya, sehingga dapat dengan lebih cerdas mengelola keuangan hariannya.

g. Peserta memahami tujuan dari pendidikan pengelolaan keuangan

Berikut ini adalah beberapa hasil dokumentasi dari kegiatan pengabdian pada masyarakat: 

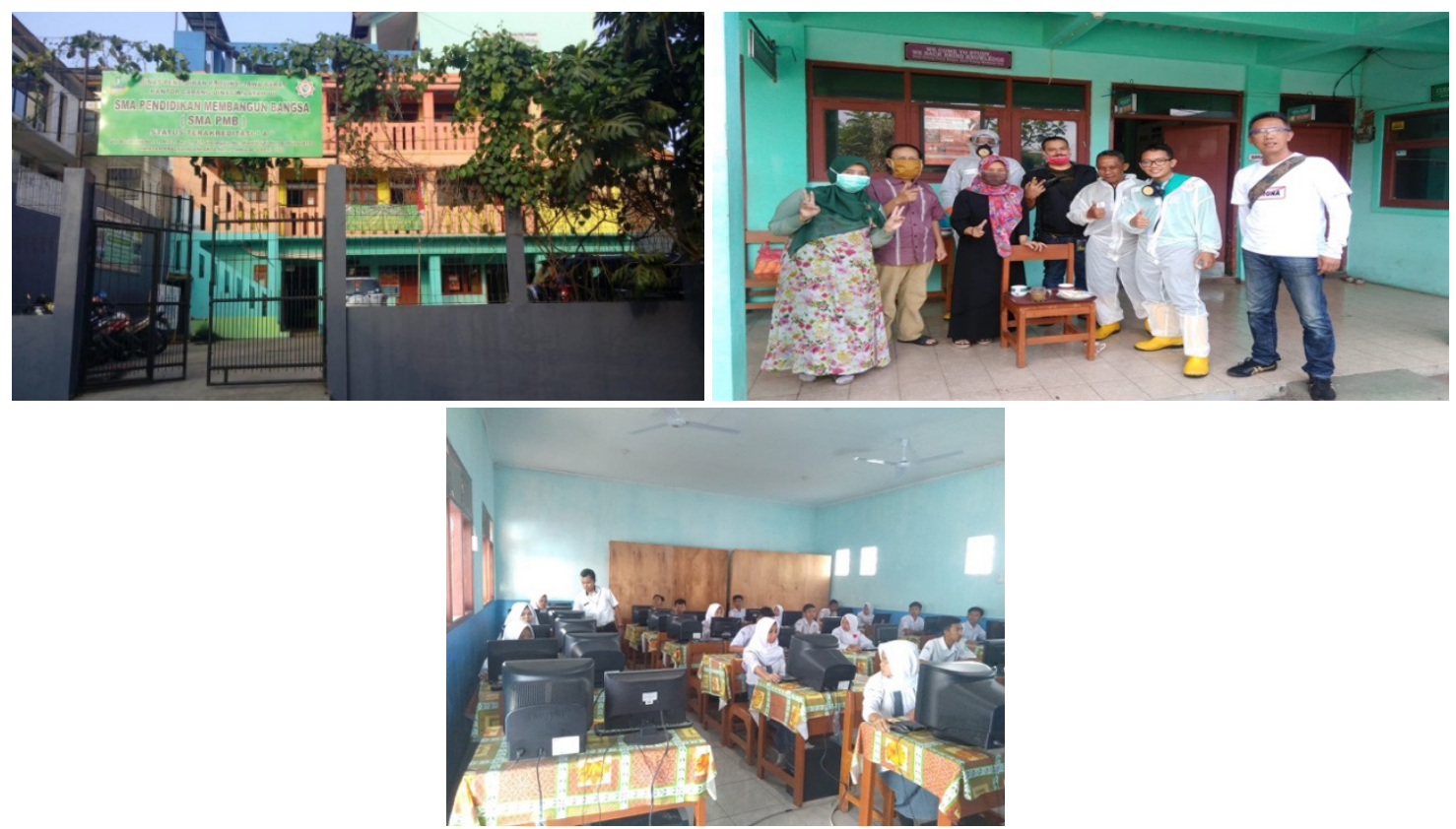

Gambar 7. Dokumentasi Kegiatan Pengabdian pada Masyarakat

Beberapa faktor yang mendukung terlaksananya kegiatan pengabdian pada masyarakat ini adalah besarnya minat dan antusiasme peserta selama kegiatan, sehingga kegiatan berlangsung dengan lancar dan efektif. Sedangkan faktor penghambatnya adalah kedisiplinan peserta dalam merealisasikan pendidikan yang mereka dapatkan dalam kehidupan sehari-hari.

\section{SIMPULAN}

Dari hasil pengabdian pada masyarakat yang dilakukan pada pelajar SMA PMB dapat dilihat bahwa mayoritas pelajar SMA PMB ini berasal dari keluarga dengan golongan ekonomi menengah ke bawah. Dari hasil praktik penyusunan anggaran didapatkan bahwa sumber pendapatan mereka adalah uang saku dengan besaran rata-rata sebesar Rp. 10.000Rp. 20.000. Dari hasil praktik ini, rata-rata para peserta memilikitujuan keuangan untuk membeli handphone, tetapi hasil penyusunan anggaran, mayoritas pelajar tidak dapat mencapai tujuan keuangan dikarenakan anggaran yang defisit. Hal tersebut disebabkan oleh adanya kesulitan dalam mengidentifikasi antara needs/kebutuhan dengan wants/keinginan yang didasari oleh perilaku konsumtif dan aktualisasi diri. Sehingga untuk menghindari defisit, salah satu caranya adalah dengan membudayakan hidup hemat seperti membawa bekal dari rumah agar tidak jajan di sekolah, ataupun budaya menabung dengan uang receh. Hal tersebut diharapkan dapat membantu para pelajar agar lebih cerdas dalam mengelola keuangan hariannya. Adapun faktor penghambat untuk membiasakan diri dengan perilaku budaya hemat dan menabung adalah kedisiplinan untuk terus menyimpan uangnya sampai tujuan keuangannya terwujud.

\section{PERSANTUNAN}

Terima kasih kepada Sekolah Tinggi Ilmu Ekonomi (STIE) Ekuitas yang telah membiayai seluruh kegiatan pengabdian pada masyarakat ini.

\section{REFERENSI}

Fattah, F., Indriayu, M., \& Sunarto. (2018). Pengaruh Literasi Keuangan dan Pengendalian Diri terhadap Perilaku Konsumtif Siswa SMA Muhammadiyah 1 Karanganyar. BISE: Jurnal Pendidikan Bisnis Dan Ekonomi, 4(1), 11 - 21. 
Yuneline, dkk - Perencanaan Keuangan untuk Menumbuhkan Awareness ...

https://www.antaranews.com/berita/405636/cetak-biru-literasi-keuangan-nasional-diluncurkan, Retrieved 16 Januari 2019

https://globalfindex.worldbank.org/ Retrieved 16 Januari 2019

https://oto.detik.com/mobil/d-4405600/heboh-petani-majalengka-beli-toyota-rush-pakai-uangreceh Retrieved 18 June 2020

Huston, S. (2010). Measuring Financial Literacy. Journal Of Consumer Affairs, 44(2), 296-316. doi: 10.1111/j.1745-6606.2010.01170.x

Islami, C., Yuneline, M., \& Suryana, U. (2020). Literasi Keuangan Pasar Modal untuk Optimalisasi Galeri Investasi Bursa Efek Indonesia STIE Ekuitas. Banking \& Management Review, 9(1), 1196 -1211. Retrieved from http://ojs.ekuitas.ac.id/index.php/bmr/article/view/261/150

Kemu, S. (2016). Literasi Pasar Modal Masyarakat Indonesia. Kajian, 21(2), 161 - 175. Retrieved from http://jurnal.dpr.go.id/index.php/kajian/article/view/773

Mawo, T., Thomas, P., \& Sunarto, S. (2017). Pengaruh Literasi Keuangan, Konsep Diri, dan Budaya terhadap Perilaku Konsumtif Siswa SMAN 1 Kota Bajawa. Journal Of Economic Education, 6(1), 60 - 65. Retrieved from https://journal.unnes.ac.id/sju/index.php/jeec/article/view/14702

Oktafikasari, E., \& Mahmud, A. (2017). Konformitas Hedonis dan Literasi Ekonomi terhadap Perilaku Konsumtif melalui Gaya Hidup Konsumtif. Economic Education Analysis Journal, 6(3), 684 - 697. Retrieved from https://journal.unnes.ac.id/sju/index.php/eeaj/article/view/20280

Putri, S., Widodo, J., \& Martono, S. (2016). Pengaruh Literasi Keuangan melalui Rasionalitas terhadap Perilaku Konsumtif(Studi Kasus Siswa Kelas XI Ilmu Sosial SMA NegeriSe-Kota Semarang).Journal Of Economic Education, 5(2), 179 - 192. Retrieved from https://journal.unnes.ac.id/sju/index. $\mathrm{php} / \mathrm{jeec} /$ article/view/13047

Sina, P. (2012). Analisis Literasi Ekonomi. Journal Economia, 8(2), 135 - 143.

Warsono. (2010). Prinsip-Prinsip dan Praktik Keuangan Pribadi. Journal of Science, 13(2), 137 - 151. Retrieved from http://ejournal.umm.ac.id/index.php/salam/article/view/470

Widyawati, I. (2015). Faktor-faktor yang Mempengaruhi Literasi Keuangan Mahasiswa Fakultas Ekonomi dan Bisnis Universitas Brawijaya. Assets: Jurnal Akuntansi dan Pendidikan, 1(1), 89 - 99. doi: http://doi.org/10.25273/jap.v1i1.527

Yudasella, I., \& Krisnawati, A. (2019). Pengaruh Literasi Keuangan terhadap Perilaku Konsumtif Siswa Sekolah Menengah Atas di Kota Bandung. Jurnal Mitra Manajemen, 3(6), 674-687. Retrieved from http://www.e-jurnalmitramanajemen.com/index.php/jmm/article/view/245

Yuneline, M., \& Suryana, U. (2020). Financial Literacy and Its Impact on Funding Source's DecisionMaking. International Journal of Applied Economics, Finance, And Accounting, 6(1), 1-10. doi: https://doi.org/10.33094/8.2017.2020.61.1.10 